\title{
Physicochemical and Bacteriological Analysis of Well Water in Kaduna Metropolis, Kaduna State
}

\author{
I. A. Allamin 1*, M. B. Borkoma², R. Joshua1, I. B. Machina ${ }^{3}$ \\ ${ }^{1}$ Department of Microbiology, University of Maiduguri, Maiduguri, Nigeria \\ ${ }^{2}$ Standard Organization of Nigeria, Lagos, Nigeria \\ ${ }^{3}$ Katsinaliason Office, National Institute of Trypanosomiasis Research, Kaduna, Nigeria \\ Email: ibnallaminmcb@unimaid.edu.ng, ${ }^{*}$ ibnallamin@gmail.com
}

Received 1 June 2015; accepted 19 June 2015; published 26 June 2015

Copyright (C) 2015 by authors and OALib.

This work is licensed under the Creative Commons Attribution International License (CC BY). http://creativecommons.org/licenses/by/4.0/

(c) (i) Open Access

\section{Abstract}

The study was carried out to determine the physicochemical and bacteriological quality of well water from Kaduna metropolis. The physiochemical quality of the water was analyzed using FAO (1997) method and the result obtained showed that the water sample was acidic, some neutral but they all fell within the range as recommended by WHO, and NAFDAC, the water sample fell within the recommended range for Nitrite, turbidity, conductivity and chloride. The bacteriological quality of the water was also determined by most probable number technique, the total coli-form count and the differential $E$. coli count in which several tubes with diluted buffered solution to dilute the water sample and then incubated for $24 \mathrm{hrs}$, this is called the presumptive test while for the confirmation test, positive tubes from the presumptive test were inoculated into separate growth medium for total coli-form and $E$. coli and then incubated. The results obtained showed that total coliforms were observed ranging from 11.0 to $63.0 \mathrm{cfu} / \mathrm{ml}$ with Sabon Tasha (TS) having the highest counts and Nasarawa (NS) with the least counts, while only two sites-Sabon Tasha (ST) and Kakuri (KK)-were recorded to have feacal contaminations. $E$. coli was identified suggesting that the water samples from the two were having recent feacal contamination.

\section{Keywords}

Physicochemical, Bacteriological, Analysis and Well Water

Subject Areas: Microbiology

\footnotetext{
${ }^{*}$ Corresponding author.
}

How to cite this paper: Allamin, I.A., Borkoma, M.B., Joshua, R. and Machina, I.B. (2015) Physicochemical and Bacteriological Analysis of Well Water in Kaduna Metropolis, Kaduna State. Open Access Library Journal, 2: e1597. 


\section{Introduction}

Water is the second essential factor for life after oxygen. If this essential factor is not available, some organisms die. Human beings are not excluded from this marvelous factor. People obtain their water from different sources and water is of paramount importance especially in developing countries where water supplies still pose an issue. Natural groundwater is usually of good quality, but this can deteriorate due to inadequate source protection and poor resource management. Mechanisms of groundwater recharge and the natural attenuation capacity also depend on soil type and geomorphologic characteristics. Groundwater contamination may be due to improper dwelling of well and waste disposal [1]. Microbial and chemical contaminations have been detected in groundwater [2]. The source of contamination is numerous and includes, land disposal of sewage effluents, sludge and solid waste, septic tank effluents, sludge and solid waste, septic tank effluent, urban runoff and agricultural mining and industrial practices.

The use of untreated and inadequately treated ground water has been responsible for water borne diseases including gastroenteritis, cholera, hepatitis, typhoid fever, and giardiasis; the causative agents are bacterial and viral pathogens as well as protozoan parasites. In contrast to chemical hazards that may pollute groundwater, resulting in a long range influence on public health in terms of time, microbiological pollution of groundwater sources has an immediate effect on a large number of people. Chemical pollutants can cause a different type of intoxication. The effects of inorganic chemicals are better known than those of trace levels of organic chemicals detected in groundwater. The list of groundwater contaminants includes hydrocarbons, metals, cyanide, arsenic various synthetic substances, soluble form of nitrogen and phosphorus, organic matter. Nitrate is one of the most common ground water contaminants in rural areas; it can enter the system from a variety of natural and anthropogenic sources (mainly fertilizer usage). Nitrate is regulated in drinking water because high levels may cause serious illness and sometimes death. It also has the potential to cause shortness of breath, methemoglobinemia or blue baby disease, an increase in starchy deposits and hemorrhage at the spleen [2]. Contamination of groundwater has severe implications for public health, particularly in small communities and developing countries where groundwater is often the preferred source of drinking water. Conformation with physiochemical and bacteriological standards is of special interest because of the capacity of water to spread disease within a large population. Although the standards vary from place to place, the objective anywhere is to reduce the possibility of spreading water borne diseases to the breast minimum in addition to being present to drink which implies that it must be wholesome and palatable in all respects [3]. Due to the increasing number of people in Kaduna state which is as a result of an increase in industries, schools (tertiary, secondary and primary schools), and vast land space for agricultural purposes, the role well water which is a major source of water cannot be over emphasized. Provision of this basic need has not been met by social bodies and government, and thus the need for an alternative and groundwater or well water has been provided by nature which is as old as man himself. The physicochemical and bacteriological quality of water is a concern to consumers, regulators and public health experts. The potential of drinking water to transmit microbial pathogens to great number of people causing subsequent illness is well reported in many countries at all levels of economic development. Therefore, it is of paramount importance to assess both physical and bacteriological standard of well water as it is the source of drinking water within Kaduna metropolis, to improve awareness and reduce the incidence of disease transmission.

\section{Material and Method}

\subsection{Study Area}

The study was conducted in Kaduna metropolis, Kaduna state, Nigeria. Kaduna state lies between latitude $9^{\circ} 30^{\prime} 0^{\prime \prime} \mathrm{N}$ and $11^{\circ} 0^{\prime} 0^{\prime \prime} \mathrm{N}$ and longitude $6^{\circ} 0^{\prime} 00^{\prime \prime} \mathrm{E}$ and $9^{\circ} 0^{\prime} 0^{\prime \prime} \mathrm{E}$ and shares boundries with Katsina, Kano and Zamfara States to the North, Plateau and Bauchi States to the East, Nasarawa State and Federal Capital Territory to the South and Niger State to the West [4]. The metropolis may be demarcated by the intersection of longitude $7^{\circ} 32^{\prime} \mathrm{E}$ and latitude $10^{\circ} 36^{\prime} \mathrm{N}$ at an altitude of about $643 \mathrm{~m}$. The climate is characterized by a rainy season (about 6 months), followed by a dry and dusty harmattan season lasting from November to February. The rainy season is preceded by a short hot dry spell with mean maximum daily temperature of between $35^{\circ} \mathrm{C}$ and $40^{\circ} \mathrm{C}$. Annual total rainfall is about $1272 \mathrm{~mm}$ and rain falls mostly from May to October [4]. Kaduna State has a population of over 6,066,562 people according to the 2006 census figures [4]. Agriculture is the main stay of the economy of the State with about $80 \%$ of the people actively engaged in animal and crop farming. 


\subsection{Sample Collection}

Water samples were collected from twelve (12) different areas located within the metropolis using a $50 \mathrm{cl}$ sterile plastic container. The collected samples were analyzed within 6 hours of collection time. The method employed in the collection of samples is random sampling technique. Three (3) wells were randomly selected from each of the towns that make up the local government area. A formal introduction is made to the household owners as an undergraduate with purpose of collection explained which is basically for research. With permission granted, water sample is drawn from the well into a sterile $50 \mathrm{cl}$ plastic container [5].

\subsection{Physicochemical and Bacteriological Analysis}

The physicochemical quality of the well water sample was analyzed for $\mathrm{pH}$, turbidity, conductivity, Nitrite and chloride as described by [6].

Bacteriological characteristics of the well water sample were determined using multiple tube fermentation method (most probable number) for enumeration of both total coli-form count and differential Escherichia coli count. Lauryl Tryptose Broth (LTB) along with fermentation tubes (Durham tubes) was used. A serial dilution of the water sample to be tested was made and inoculated into LTB growth media. Samples were then incubated at $35^{\circ} \mathrm{C}$ for $48 \mathrm{~h}$ for the presumptive test for total coliform count. After the positive tubes were transferred to Brilliant green lactose bile broth (confirmationtest) and incubated for $48 \mathrm{~h}$ at $35^{\circ} \mathrm{C}$, the growth or gas production confirmed the presences of coliform [5].

\section{Results and Discussion}

The physicochemical parameters of the water samples from the twelve (12) areas within Kaduna metropolis were analysed. The result as shown in Table 1 indicates that the $\mathrm{pH}$ ranges from 6.1 to 7.3 and the lowest was recorded at Sabon Tasha (ST) and highest $\mathrm{pH}$ at Riga Chuku (RC) and the $\mathrm{pH}$ level was within the standard of both WHO and NAFDAC, even as pH has to clear health implication to human health, but it action on physiological processes cannot be overemphasized [7]. Water sample from Malali (ML) had the highest temperature of $33.1^{\circ} \mathrm{C}$.

The turbidity of the water sample was higher with a range of 3.4 to 4.8 at Barikin Lahu (BL) and Mando (MD) respectively which are very close to the standard limit by WHO and NAFDAC of 5.0 this is indicating that the well water relatively turbid this may be due to parental rock activities, Water turbidity is very important because high turbidity is often associated with higher level of disease causing microorganism, such as bacteria and other parasites [5]. The presence of TDS in water may affect its taste [8]. It has been reported that drinking water with extremely low concentration of TDS may be unacceptable because of its flat insipid taste [5] [8]. And conductivity ranged from 183 to 197. Also, fluoride content of all water samples fell within the standard limit of WHO and NAFDAC (1.5 mg/l), likewise the copper content of all the water samples used in this study which is in agreement with WHO and NAFDAC standard of $1 \mathrm{mg} / \mathrm{l}$. Although, presence of copper above the standard set by NAFDAC may cause gastrointestinal distress with a shorter term exposure, while a long term exposure may experience liver or kidney damage [9]. Likewise the Iron content of the water sample with 0.0 to 0.1 which is of relative concern while chloride and nitrite both ranged from 16.5 to 45.9 and 0.1 to 0.6 respectively, The implication of this might be as reported by [10], about 4500 billion liters of contaminated water seeps into the ground in the United States every day from septic tanks, oil wells, landfills, agricultural and ponds holding hazardous waste Unfortunately, very little is known about the extent of groundwater contamination (Table 1).

Table 2 shows the bacteriological analysis of water from well within Kaduna Metropolis. The total coliform count within the twelve (12) different sites range from 11.0 to $63.0 \mathrm{cfu} / \mathrm{ml}$ and with water from Kakuri (KK) and Sabon Tasha (TS) having the highest counts of 63.0 and 60.0 respectively, while water from Nasarawa (NS) recorded the lowest counts of $11.0 \mathrm{cfu} / \mathrm{ml}$. The total coliform counts of all the water samples were generally high. They exceeded the standard requirement of 10 total coliform counts per $100 \mathrm{ml}$ for NAFDAC and zero total coliform count per $100 \mathrm{ml}$ for WHO [5]. The implication of this finding is that water from these wash well may look clean to naked eye and have no unwanted odour or taste but contains pathogenic bacteria that can cause significant illness such as gastrointestinal, urinary tract infection (UTI) tract infections, which may even become fatal in severe condition. The results of this study correlate with the report of Bello et al., [7] who showed that the water samples from well was highly contaminated with coliform bacteria. However, with the 
Table 1. Physicochemical analysis of well water from Kaduna metropolis.

\begin{tabular}{|c|c|c|c|c|c|c|c|c|c|c|c|c|c|c|c|}
\hline $\mathrm{S} / \mathbf{N}$ & Parameter & ST & NY & $\mathbf{K Y}$ & B N & KK & NS & UR & ML & BD & MD & BL & RC & WHO & NAFDAC \\
\hline 1. & $\mathrm{pH}$ & 6.1 & 6.8 & 6.5 & 7.2 & 6.5 & 7.1 & 7.1 & 6.6 & 7.0 & 6.7 & 7.1 & 7.3 & $6.5-8.5$ & $6.5-8.5$ \\
\hline 2. & $\begin{array}{c}\text { Temperature } \\
\left({ }^{\circ} \mathrm{C}\right)\end{array}$ & 30.0 & 31.0 & 30.2 & 31.5 & 30.5 & 31.1 & 29.8 & 33.1 & 30.7 & 30.6 & 31.1 & 30.9 & 40.0 & Ambient \\
\hline 3. & Turbidity (ntu) & 4.7 & 4.6 & 4.6 & 4.3 & 4.1 & 3.8 & 3.7 & 3.9 & 3.8 & 4.8 & 3.4 & 4.1 & $5-25$ & $0-5$ \\
\hline 4. & $\begin{array}{c}\text { Conductivity } \\
(\mu \mathrm{s} / \mathrm{cm})\end{array}$ & 183 & 188 & 191 & 191 & 196 & 197 & 190 & 188 & 187 & 190 & 194 & 191 & 250 & 1000 \\
\hline 5. & Chloride mg /L & 37.5 & 40.9 & 41.9 & 25.9 & 28.3 & 20.2 & 22.5 & 45.9 & 49.2 & 16.5 & 21.8 & 30.9 & 250 & 250 \\
\hline 6. & Nitrite mg/L & 0.6 & 0.6 & 0.6 & 0.4 & 0.4 & 0.4 & 0.1 & 0.1 & 0.5 & 0.5 & 0.5 & 0.5 & 5.0 & 4.0 \\
\hline 7. & Iron mg/L & 0.0 & 0.0 & 0.1 & 0.0 & 0.1 & 0.0 & 0.0 & 0.0 & 0.0 & 0.0 & 0.0 & 0.0 & - & 0.1 \\
\hline 8. & Copper mg/L & 0.44 & 0.34 & 0.50 & 0.33 & 0.45 & 0.40 & 0.60 & 0.60 & 0.58 & 0.29 & 0.30 & 0.69 & 1.0 & 1.0 \\
\hline 9. & $\begin{array}{l}\text { Total dissolved } \\
\text { solid (TDS) } \\
\text { mg/L }\end{array}$ & 455 & 600 & 560 & 666 & 609 & 700 & 546 & 768 & 749 & 608 & 709 & 688 & 1500 & 500 \\
\hline
\end{tabular}

Sabon Tasha (ST); Narayi (NY); Karji (KJ); Barnawa (BN); Kakuri (KK); Nasarawa (NS); Ungwar Rimi (UR); Malali (ML); Badarawa (BD); Mando (MD); Barkin Lahu (BL); Riga Chuku (RC).

Table 2. Bacteriological analysis of well water from Kaduna Metropolis.

\begin{tabular}{ccc}
\hline Sample sites & Total coli form count & Differential $\boldsymbol{E}$. coli count \\
\hline Sabon Tasha (ST) & 63.0 & 2.0 \\
Narayi (NY) & 25.0 & ND \\
Karji (KJ) & 22.0 & ND \\
Barnawa (BW) & 35.0 & 1.0 \\
Kakuri (KK) & 60.0 & ND \\
Nasarawa (NS) & 11.0 & ND \\
Unguwar Rimi (UR) & 23.0 & ND \\
Malali (ML) & 30.0 & ND \\
Badarawa (BD) & 32.0 & ND \\
Mando (MD) & 20.0 & ND \\
Barkin Lahu (BL) & 25.0 & 0 per $100 \mathrm{ml}$ \\
Riga Chukwu (RC) & 18.0 & 0 \\
WHO standard & 0 per $100 \mathrm{ml}$ & per $100 \mathrm{ml}$ \\
NAFDAC standard & 10.0 & No \\
\hline
\end{tabular}

ND = Not detected.

exception of water sample from Sabon Tasha (ST) and Kakuri (KK) which had the fecal coliform count of 2.0 and $1.0 \mathrm{cfu} / \mathrm{ml}$ respectively this indicated recent faecal contamination and might be due to the close proximity of the well to commercial toilet as is seen at Sabon Tasha (TS), but all the remaining samples have zero fecal coliform count, which indicate that the water samples are free from recent faecal contamination.

\section{Conclusion}

The importance of water in sustenance of life fascinates the attention of governmental and non-governmental 
organizations such as WHO and NAFDAC to establish the standard of the drinking water quality. The importance of access to good quality water cannot be overemphasized. Increase in population in Kaduna Metropolis coupled with the rise in human activity poses a great pressure on provision of safe drinking water. This necessitates large number of people to consume water from wells which constitute a major health problem due to close proximity of wells to either source of contaminations. This study recorded high number of coliform counts in water samples analyzed, thus making it unsafe for drinking and require further treatment. Therefore, there is an urgent need for awareness to be created about the present situation of these wells; peoples should to enlighten the people on the necessity for further treatment of this water before they can be used for drinking and domestic purposes and wells should be drilled some meters far away from any source of contaminations.

\section{References}

[1] Nkuma, A.F. (2010) Physiochemical Analysis of Well Water from Wells Sited Close to Outside Sanitation System. M.Sc. Thesis.

[2] Pritchard, M., Mkandawire, T. and O’Neil, J.G. (2008) Assessment of Groundwater Quality within the Southern Districts of Malawi. Physics and Chemistry of the Earth, 33, 812-823. http://dx.doi.org/10.1016/j.pce.2008.06.036

[3] EPA (2012) Environmental Protection Agency Basic Information about Copper in Drinking Water. http://water.epa.gov/drinking/contaminants/basic information/copper.cfm

[4] Kaduna State Government (KDSG) (2008) Kaduna State Achievements in Data on Estimated Annual Animal Populations and Fish Production Investment Opportunities in Kaduna State. 16-18.

[5] Isa, M.A., Allamin, I.A., Ismail, H.Y. and Shettima, A. (2013) Physicochemical and Bacteriological Analyses of Drinking Water from Wash Boreholes in Maiduguri Metropolis, Borno State, Nigeria. African Journal of Food Science, 7, 9-13. http://dx.doi.org/10.5897/AJFS12.073

[6] FAO (1997) Chemical Analysis Manual for Food and Water. 5th Edition, FOA, Rome, 20-26.

[7] Bello, H.S., Isa, M.A., Shettima, A. and Allamin, I.A. (2013) Physicochemical and Bacteriological Contamination of Drinking Water from Wash Bores in Jere, Borno State, Nigeria. Journal of Microbiology and Biotechnology Research, 3, 126-131.

[8] WHO (2006) Guidelines for Drinking Water Quality. 3rd Edition, WHO Press, Geneva, 398.

[9] Edama, M.D., Omemu, A.M. and Fapetu, O.M. (2001) Microbiological and Physiochemical Analysis of Different Sources of Drinking Water in Abeokuta, Nigeria. Nigerian Journal of Microbiology, 15, 57-61.

[10] Miller (Jnr), G.T. (1997) Environmental Science, Working with the Earth. 6th Edition, Wadsworth Publishing Company, USA, 285-286. 